IRA-International Journal of Management \& Social Sciences

ISSN 2455-2267; Vol.06, Issue 02 (2017)

Pg. no. 306-313

Institute of Research Advances

https://research-advances.org/index.php/RAJMSS

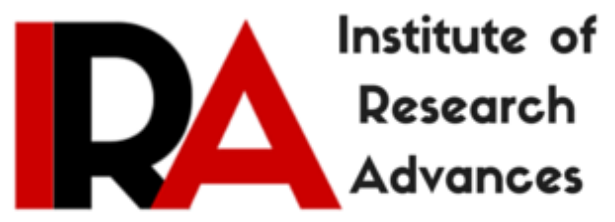

\title{
Business Responsibility Reports- A Case Study of ITC Ltd.
}

\section{Ankita Kashyap}

Asst. Professor, Shaheed Bhagat Singh College, University of Delhi, India.

Type of Review: Peer Reviewed.

DOI: http://dx.doi.org/10.21013/jmss.v6.n2.p15

\section{How to cite this paper:}

Kashyap, A. (2017). Business Responsibility Reports- A Case Study of ITC Ltd.. IRAInternational Journal of Management \& Social Sciences (ISSN 2455-2267), 6(2), 306-313. doi:http://dx.doi.org/10.21013/jmss.v6.n2.p15

(C) Institute of Research Advances

\section{(c)) EY-NO}

This work is licensed under a Creative Commons Attribution-Non Commercial 4.0 International License subject to proper citation to the publication source of the work.

Disclaimer: The scholarly papers as reviewed and published by the Institute of Research Advances (IRA) are the views and opinions of their respective authors and are not the views or opinions of the IRA. The IRA disclaims of any harm or loss caused due to the published content to any party. 


\begin{abstract}
The paper focuses on the various National/ international guidelines that exist globally on Corporate Social Responsible Behaviour. These guidelines include National Voluntary Guidelines on Social, Economic and Environmental Responsibility (NVGs), ISO 26000, GRI G3.1 Sustainability Guidelines, AccountAbility's AA 1000 Standards and UN Global Compact. The author has tried to compare the above mentioned guidelines in order to find out the additional elements that should be included in Business Responsibility Reports to make disclosures and reporting on CSR more comprehensive.

The Business Responsibility Report of ITC Ltd. is studied and analyzed to find out the missing elements in its disclosures. The study specifically analyses the disclosures made by the company with respect to Principle 2, 4 and 9 of National Voluntary Guidelines. I have tried to analyse the disclosure made by the company on the basis of these five parameters 1) Disaggregated information 2) Sustainability quantification 3) Stakeholder engagement 4) customer engagement and 5) Consumer satisfaction.

This paper tries to find out the quality of disclosures made by ITC Ltd. in its BRR with respect to social, economic and environmental responsibilities. The main aim of the paper is to analyze the effect of social responsibility practices on different stakeholders. Does the BRR submitted by the companies as part of their Annual Reports really lead to value creation for the stakeholders? Or the reports try to create only a façade of their social responsibility practices to deceive the stakeholders? We try to lift this veil behind their reporting practices to find out their actual social behavior.
\end{abstract}

Keywords: ITC, BRR, CSR, NVGs, ISO 26000

\title{
1. Introduction
}

Corporate social responsibility (CSR) is gaining importance in India post amendment of the Indian Companies Act, 2013. CSR means a social obligation that an organization has towards different constituents of the society in which it operates. It means behaving ethically and in a responsible manner to create a positive impact on the society. According to Greenfield's assumptions organization is considered as a legal person and being a person that belongs to the society, it has some obligation towards people at large. (Aguero Aan \& Martinez Luis Juan, 2005)

CSR has lot of advantages ranging from ethical programming of the individuals to realizing the responsibilities of a firm towards various stakeholders and also upliftment of the deprived. But, there is also criticism for the same. Organizations may already be following various social practices but CSR compels them to report the activities in a proper format and assign monetary value to it which might undermine the basic purpose of carrying out CSR activities. However, on the whole as CSR leads to improvement in the environment \& the society, its benefits outnumber and therefore are worth following.

\section{National/ International Guidelines on Social Responsibility}

\subsection{National Voluntary Guidelines (NVGs)}

These guidelines are brought out by the Ministry of Corporate Affairs in association with India Institute of Corporate Affairs (IICA) to help Indian companies and also Multi-National Corporations (MNCs) operating in India to carry out the social responsibilities towards different stakeholders. These guidelines provide nine principles and advocate that the companies (whether large or small) should follow all these principles rather than choosing the ones that might suit them. 


\subsection{ISO 26000}

International Organization for Standardization (ISO) is a body which formulates various product and service standards and certification schemes so that globally organizations adhere to certain standards in conducting their business practices.

ISO 26000 was developed in 2010 following a multi-stakeholder approach wherein views of different stakeholders were integrated and incorporated. ISO 26000 provides only guidance to firms in carrying out their social responsibilities. It neither provides certification nor is a regulation, it is only a voluntary set of guidelines which an organization should voluntarily respect \& obey to become a socially responsible entity (ISO26000, 2010)

\subsection{National Voluntary Guidelines (NVGs) Vs. ISO 26000}

In comparison between ISO 26000 guidelines and NVG, we find that though both cover the issues and standards pertaining to the corporate social responsibility but the former (ISO 26000 guidelines) is more elaborate and explanatory as compared to the National Voluntary Guidelines. ISO26000 provides point by point detailed description of every clause. It is further divided into sub-clauses and explained at length. NVG also somewhat explain the same standards with minor alterations but is not comprehensive as ISO 26000 and leave much to the imagination. Hence, we can say NVG is more or less a summarization of detailed version of CSR practices laid down in ISO26000 guidelines.

Though NVG has been made a mandatory for top 100 listed companies (by market capitalization) but indepth explanation and expectation to the business social responsibilities and the methods of its application have not been elaborated. NVG just provide some general principles and leave Indian corporates in dilemma as to how to apply and comply with the legal mandate issued by SEBI. It will be an eye opener to see the reporting by Indian companies to see how they and their annual reports in 2013 interpret the different clauses for integrating reporting purposes. Also, NVG provides enough scope for defense of the company in not carrying out the social practices as no comprehensive or inclusive practices have been stipulated.

\section{4 GRI G3.1 Sustainability Guidelines}

Global Reporting Initiative (GRI), located in Netherlands was formed by United States with support of United Nations Global Compact. It is a non- profit organization that provides sustainability guidelines and reporting framework. 'G3 Third Generation', GRI's Sustainability Reporting Guidelines were introduced in 2006. 'G3.1' are an updated version over G3. Guidelines G3.1 consists of economic, social and environmental performance indicators. Following this as a standard of measuring and reporting sustainability performance provides transparent and accountable disclosures and hence helps increase the stakeholders' confidence. (G3.1 Sustainability Reporting Guidelines, 2011). 'G4 Fourth Generation' Guidelines are a recent addition to GRI Standards. It is an up-gradation of G3.1 Sustainability Guidelines and is the result of constant advancement and improvement of the standards laid down by GRI.

\subsection{NVGs Vs. GRI G3.1 Sustainability Guidelines}

On comparison it is found that, Business Responsibility Reports prescribed by SEBI in accordance with NVG follow Apply or Explain approach. It requires Indian companies to only map their reports in accordance with NVG principles. NVGs focus on organisations' report in view of their mission and vision i.e. reporting on topics which are relevant and important in connection to their business activities. NVGs emphasis is on development of strong bond between stakeholders and business entities. 
On the other hand, GRIs follow Report or Explain approach. In this the companies are required to explain their reasons for non-compliance of the principles laid down. GRI Guidelines help organisations in measuring and reporting the sustainable activities followed by them. GRI provides global standards with specific sector supplements and unique issues. GRI takes into consideration the view- points and opinions of diverse groups of stakeholders. These guidelines focus on Materiality Principle and also provide a Protocol that help organisations in choosing the content and principles for reporting based on its materiality. GRI focus is to first identify the stakeholders that are related to the business entity and then explaining the report to the concerned stakeholders. It also stresses on the need to explain as to how the report addresses the concerns of the related stakeholders. (GRI Focal Point, 22.02.2013)

Though both apply to companies of all sizes and structures but NVG is more general in its approach and use. Thus GRI and NVG are complementary in nature and should be used together in order to increase the credibility of reporting.

NVG provide no link or relation to the already established international standards in respect of social responsibility .The worldwide standards in social responsibility context like the AA1000 standards, GRI G3 and G3.1 guidelines and ISO26000 provide implementation approaches to social practices, lists down social, economic, environmental indicators, checklists tests to comply for credible policies on social responsibility, reporting framework for proper documentation, process for communicating it to stakeholders etc. NVG lack in these above mentioned aspects. Also, Indian corporates are new to this concept of adhering to the sustainability standards and hence require more detailed and elaborateguidelines which are not met by the National Voluntary Guidelines.

Thus, National Voluntary Guidelines should be used in conjunction with the international standards on social responsibility like ISO26000, GRI G3.1 Guidelines. These international guidelines are hence complementary documents to NVG. Indian corporates should seek guidance on ambiguous issues from these international guidelines and framework on social responsibility.

\section{FMCG Sector}

Fast Moving Consumer Goods is one of the biggest industries in the world. It includes all the daily use commodities that the consumers require in their day to day lives. The different everyday items included in FMCG product involve, shampoos, soaps, toothpastes, coffee, tea, soft drinks, cosmetic products, nondurable consumer electronics, stationery products etc. The commodities included in the FMCG sector are high on consumption and thus are frequently purchased. This sector is one of the fastest changing and continuously evolving sector as the needs and preferences of consumers change quickly. India is a populated country and thus there is a huge demand for these daily consumables. This sector in particular touches different parts of the country including both the rural and urban areas. These companies can connect with more consumers as they deal in day-to-day products that have a wide reach.

As this sector directly touches the consumers on an everyday basis, it would be interesting to find out as to how does the social responsibility behaviour of a company, ITC Ltd., belonging to this sector effect one of the largest stakeholders' group i.e. Consumers.

\section{ITC Ltd. - Case Study}

\subsection{History}

Found in the year 1910, ITC is India's one of the biggest FMCG Company. Initially incorporated under the name 'Imperial Tobacco Company of India Limited' the Company changed its name to ITC Limited in the year 2011. With its headquarters in Kolkata, Company invested first sixty years in Cigarettes and 
Leaf Tobacco business. It was followed by the bold step of shifting its focus to hospitality sector in 1975 with acquisition of a Chennai hotel. Company is now proud owner of renowned 5 star hotel chains in India. Since then Company has diversified into many consumer products and has become one of India's most valuable FMCG Company.

\subsection{Product Line}

The Company has forayed into different sectors such as cigarettes \& tobacco products, packaging \& printing, hospitality, paperboards, agricultural commodities, stationery products, lifestyle retailing, information technology, packaged food products, personal care products, and Agarbattis business. The Company is also into manufacturing \& exporting of garments through its subsidiary in Nepal, Surya Nepal Private Limited. The Company has 31,000 employees, 462,000 shareholders and has successfully created household brand names such as Aashirwad, Bingo, Fiama Di Wills, mint-o, classmate and many more.

\subsection{Financials}

With a turnover of more than US\$ 7 billion, the Company is considered as one of ten most valuable brands of India. The Company is amongst the largest earners of foreign exchange in India with nearly US\$ 6 billion earnings in the last ten years and more than half of it on account of agri exports. Its market capitalisation is over US\$ 45 billion and the market worth of its cigarette business is around US \$6 billion. The total share of cigarettes/ tobacco products of ITC in its total product line is around $13.33 \%$

\subsection{CSR History:}

The Company has policies in place for environment $\&$ health safety, prohibition of child $\&$ forced labour, equal opportunity for all and responsible sourcing. The Company has set-up ITC Education Trust, ITC Rural development and Sangeet Research Academy for the benefit of general public. As a part of its CSR initiative, Company also has a policy for minimizing E-Waste, material subsidiaries and food wastage. The Company has shown keen interest in research \& development activities over the last 100 years and has set-up R\&D Centres at Bhadrachalam, Rajahmundry and Gurgaon. The Company was the first from India to publish its sustainability report in Compliance with the GRI G3 guidelines.

\section{ITC Ltd. Analysis}

During the analysis of ITC Ltd. it was found that the company in its Sustainability Report does not talk about a very material aspect i.e. the effect of its major line of operation Cigars and Tobacco on the health of the society.

ITC brand name is always synonymous to the tobacco business despite the fact that it has ventured into different lines of business activities. The earliest and major area of operation still remains cigarettes and tobacco products. ITC Ltd. cannot ignore this issue as it is a substantial part of the Company and its revenue. The Company nowhere in its sustainability report even mentions about ill effects caused by the its tobacco, cigars, cigarettes etc. and how the Company addresses the issue of deteriorating health of general people by tobacco consumption. ITC's report does not mention anything regarding the negative aspects or unfavorable results of the practices related to its tobacco business.

Business Responsibility Report of ITC Ltd. was analyzed in view of the disclosures made by the company and the information available on the public domain. The Company has completely overlooked this principle of Materiality and Balance as guided by GRI. (ITC Sustainability Report 2012)

After analyzing the report of ITC Ltd., the following conclusions have been arrived at. 
5.1. Quality of Disclosures: The disclosures made by ITC in the BRR are insufficient. It does not detail the results and outcomes of its social responsibility practices.

a) Disaggregated information: The Company does not provide bifurcated responses to the BRR questions. Congregated answers are provided for the questions in its responsibility report.

b) Material information: ITC claims to be the first India Company to follow GRI Sustainability Guidelines on reporting but it has severely lacked on a very important principle of these guidelines i.e. the materiality principle. Their report talks about all the responsible work done ranging from water conservation to reduction in energy conservation, forming e-Choupals for rural development etc. but does not mention anywhere in the report about the negative health impacts being caused due to its major product line, i.e. cigarettes, tobacco and tobacco products. The health effects being caused to the consumers due to smoking both active and passive are nowhere mentioned in the report. Materiality principle of GRI Sustainability Guidelines clearly states that the Company cannot choose particular aspects on which it discloses information and conveniently avoid other relevant information.

c) Balance of Information: The negative aspects/ effects of its product (tobacco, cigarettes and products of tobacco) are nowhere detailed in the report. Non- disclosure of crucial information is treated at par with wrong disclosure. ITC has failed miserably on this front. The Company is obligated to highlight the negative effects caused by its products as well. So we can say the balance of disclosure is not followed by the Company.

d) Comparable Information: the Company does not provide comparable information on different sustainability aspects.

e) Inadequate reporting: The reporting can be far more elaborate than it is currently.

5.2. Sustainability Quantification- ITC claims to have contributed towards rural development through its programme called e-Choupals. But in its report it does not mention the outcome of such initiatives followed. The success of programmes like these can be gauged only through statistical facts and supporting data which is missing in the report.

a) Recycling of Products: ITC's BRR does not mention any activity followed for recycling of the product. It deals with several fast moving consumer goods. It should have policies on collecting the empty containers of used products and design mechanisms to recycle these as they add up to the environmental pollution.

b) Recycling of Wastes: Company has reported the activities undertaken to reduce waste generation and claims $>10 \%$ of waste recycle but does not mention the recycling of waste product wise.

c) Energy reduction: The report mentions the resoure use reduction and also lists down the different types of reenwable energy used but the data provided to support its claim on energy reduction is not on a comparable basis.

d) Green house gases emissions: It claims to be a Carbon Positive Company but does not mention about the activities undertaken to reduce green house gases emissions.

e) Sustainable sourcing: The report details about the sustainable sourcing and mentions different initiatives undertaken for this. The report mentions activities like sustainable agricultural practices, material sustainability, sustainable livelihoods etc.

5.3. Stakeholder Engagement- Though the answers to questions on stakeholder engagement suggest that due process was carried out but again it has not been backed with substantial facts. However, the Company mentions various initiatives undertaken to cater to th needs of the community including marginalized stakeholders but the identification process of stakeholders including the marginalized stakeholders is not clearly stated. The outcomes and results of stakeholder engagement have not been mentioned. 
a) Mapping of internal and external stakeholders: The Company lists down the stakeholders that it engages with.

b) Identifying marginal stakeholders: The Company claims to identify marginalized stakeholder.

c) Procedures for identification: ITC claims to have procedures in place for stakeholder engagement, but does not detail them in the BRR. This makes us to question the sanctity of the claims made by the Company. Also, though the Company has procedures for identifying the stakeholders but has no specific procedures to identify the vulnerable and marginalized stakeholders in particular.

d) Level and method of engagement: The level and the method of engagement are not at all detailed in the report.

e) Communication to stakeholders: The Company does not provide any detail if the engagement undertaken leads to some initiatives being followed for specified stakeholder and whether these initiatives were communicated to the relevant stakeholder groups.

\subsection{Customer Engagement}

a) Consumer dispute resolution: the report does not detail any preventative measures under taken to avoid consumer cases and complaints.

b) Responsible Trade Practices: Case pending against the Company on anti-competitive practice has been concealed in the report. The Company has a case pending in the Competition Commission for cartelization of paper.

c) Fair Trading and Equity to Consumers: The Company provides no information again for the fair practices of the Company.

d) Customer cases: The report provides no information regarding the customer cases and the customer complaints pending against the Company.

e) Consumer's education: BRR does not detail any activities undertaken to spread consumer awareness and education.

\subsection{Customer Satisfaction}

a. System for feedback: The Company claims that it carries out consumer survey to gauge the customer satisfaction but does not mention the frequency of consumer survey. The Company follows different ways to engage with consumers like market surveys, customer satisfaction survey, events, visits, dealer customer end user etc.

b. Consumer policy and procedures for Customer Satisfaction: The Company does not have guidelines and the code of conduct while dealing with the consumers.

c. Customer data privacy: Provides no details and measures undertaken to protect the data collected during the consumer survey.

d. Consumer's health and safety: No details are provided regarding the activities undertaken to ensure consumer health and safety.

e. Product labeling: For product labeling ITC claims to follow packaged food labeling with nutrition labeling over and above the statutory local laws.

\section{Research Findings}

The first and foremost thing related to the FMCG sector is their network. The companies of this sector have a huge distribution network which enables them to make their products available even to the most interior and rural parts of India. The trade to commerce that helps these companies to fulfill this act is the "Transportation" activity. Huge number of their trucks pedals all around the country distributing these fast moving consumer products far and wide. 
Transportation despite being such an important activity of the FMCG companies, finds very less emphasis in company's sustainability disclosures. Under Principle 2 of NVGs, BRR pertinently asks the companies in question 3 about their sustainable sourcing including transportation. To this question, ITC Ltd. have answered satisfactorily.

The FMCG companies also do not lay proper emphasis on recycling of products. The fast moving products are highly consumed. The packages of these products contribute to the environmental pollution to a large extent. For this companies should have campaigns and programmes to collect the empty cartons of products from the consumers and recycle these product containers. To these aspects ITC has not satisfactorily reported in its BRRs.

Again, another major aspect that needs immediate attention by the FMCG sector is on the stakeholder engagement. We find that though ITC is claiming to indulge in stakeholder engagement but the actual picture is different. The company does not mention their level of engagement with different stakeholder groups, the ways and methods followed to engage with the stakeholders, the result of engagement and the activities followed to address the concerns raised during the stakeholder engagement. All these details are missing from ITC's disclosure reports.

Moreover, for the FMCG sector their goods are directly connected to the consumers. The consumer is the king both for the Company's survival and growth. So, more proactive engagement is required with the consumers to understand their wants, concerns and demands that needs to be addressed.

On the whole we can say ITC's report has concealed much more than it has reported in its Business Responsibility Reports. Far more disclosure with much more transparency is required from ITC.

\section{References}

1. Accountability AA1000 Standards $(2010 \& 2011)$, http://www.accountability.org/standards/aa1000ses/index.html

2. Aguero Aan \& Martinez Luis Juan (2005), The When, Why \& How of Corporate Social Responsibility, IE Working Paper, http://ssrn.com/abstract=1015859

3. Amendments to Schedule VII of Companies Act, 2013, retrieved from: http://www.mca.gov.in/Ministry/pdf/Amendment_Notification_06082014.pdf

4. G3.1 Sustainability Reporting Framework (2010), Global Reporting Initiative, https://www.globalreporting.org/resourcelibrary/G3.1-Guidelines-Incl-Technical- Protocol.pdf

5. ISO 26000 (2010), International Standard Organisation.

6. ITC Sustainability Report 2012, retrieved from: http://www.itcportal.com/sustainability/sustainability-report-2012/index.aspx

7. ITC Ltd., http://www.itcportal.com/

8. Ministry of Corporate Affairs (2011), National Voluntary Guidelines on Social, Environment and Economic Responsibility for business, http://www.mca.gov.in/Ministry/latestnews/National_Voluntary_Guidelines_20 11_12jul2011.pdf

9. The Companies Act, 2013, Schedule VII, retrieved from: http://www.mca.gov.in/Ministry/pdf/CompaniesAct2013.pdf http://www.mca.gov.in/Ministry/pdf/Notification_03April2014.pdf http://www.mca.gov.in/Ministry/pdf/Amendment_Notification_06082014.pdf 